\title{
The Quality of External Audit in OHADA Space: A Qualitative Study with Board of Director's Members' Perception as Understanding Variable
}

\author{
Osée Hanko ${ }^{1}$ \\ ${ }^{1}$ Department of Economics and Management, University of Buea, Cameroon \\ Correspondence: Osée HANKO, Department of Economics and Management, University of Buea, Cameroon.
}

Received: January 18, 2015

Accepted: February 15, 2016

Available online: February 23, 2016

doi:10.11114/afa.v2i2.1309

URL: http://dx.doi.org/10.11114/afa.v2i2.1309

\begin{abstract}
Audit quality has been evaluated in academic literature accordingly with auditor qualities, due to the difficulties of observing auditing technical process itself. The qualities of a good auditor are then competence and independence, sine qua none conditions of audit quality. That approach is otherwise valid only if there is a valuable framework like stock market where auditor's competence and independence could be observed. In OHADA space countries, the financial market is approximately off. It is therefore impossible to assess audit quality the way it has been done in prior literature. This study suggests a new approach of assessing audit quality in OHADA countries in relation with audit committees member's perception of auditing process. Using an innovative qualitative approach inspired from Manita (2008), the results suggest to take into account the auditor's knowledge of the company, the relevance of the identified zone of risks and the degree of communication with the board of directors.
\end{abstract}

Keywords: Audit quality, Technical audit process, OHADA space countries, financial market

\section{Introduction}

Following the agency theory of Jensen and Meckling (1976), Watts and Zimmerman (1981, 1986) will elaborate the positive accounting theory, extensive research program within which research in auditing will be developed. The studies up to now conduct on audit quality were made for the overwhelming majority in the foreign developed countries. Those countries, in addition to the basic structural differences that could be underlined at the level of economic development and functioning, present a legal system adapted to their economic realities.

The OHADA countries have not yet been the venue of a serious study on external audit quality. Their specific characteristics could explain that situation: the environment is hostile to information and do not disclose it automatically as we can see abroad, the financial market is off functioning or present a low level of transactions with just few listed companies, and the legislations governing audit practice are stationary and at times conflicting themselves.

In different environments where information is available and regulated trough the stock exchange market and control bodies, external audit quality have been assessed trough two main indicators: Auditor competence and auditor independence (De Angelo, 1981). Auditor competence refers to the capacity of the auditor to detect fraud or any material misstatement in the audited financial statements of his client, while independence refers to the capacity of the auditor of revealing any anomaly discovered. Audit quality is then the double probability for an auditor to discover and to reveal to the market any fraud or material misstatement within the financial statements he has audited.

The specific characteristics of OHADA countries environment make difficult the use of the same theoretical indicators (auditor's competence and independence) for assessing external audit qualities taken from well functioning stock market countries. This study intends then to suggest new indicators for assessing external audit quality, which takes into account specific environmental characteristics. It hopes to achieve audit quality items adapted to OHADA countries environment, applicable to the context, based on the technical audit process itself.

The research will be presented in four main points. A literature review will make us revisit existing theoretical indicators and how they were treated, with what results. This approach will lead us to underline the shortcomings of such an approach, and to see why it could not been used in OHADA environment (1). Then, the methodology of obtaining new indicators will be presented and discussed (2). Finally, the results and their implications will be presented and discussed. 


\section{Assessing External Audit Quality: A Literature Review}

Auditing is a technical process which is difficult to observe. Due to that, authors decided to assess audit quality not by trying to observe that unobservable process, but by referring themselves to the auditor's quality (Manita, 2008). The quality of audit became the quality of auditor: Two main characteristics were studied here: Auditor competence and auditor independence

\subsection{Assessing auditor competence}

De Angelo (1981) defines competence as the ability for an auditor to discover a fraud in the financial statements of the client. The literature reports that a qualification and sufficient experience are the main weapons of an auditor competence skills (Flint, 1988), while structural and organizational characteristics and large size appear to be determinants of competence in cases where auditor is CPA firm (Fama and Jensen, 1983). This is explained by the fact that it is considered that a large CPA firm attracts more well trained and qualified auditors, they have enough resources, and can redeploy them normally as part of a mission (De Angelo, 1981 ; Watts and Zimmerman, 1986; Adjaoud, 2007). The negligence of employees of the partner to whom is entrusted the mission was also discussed, as a factor to avoid raising the level of competence (Chow, Cooper and Waller, 1988; Malone and Roberts, 1996).

With the scandals that the area of auditing has experienced in the early 2000s, one of the reforms introduced by the laws that followed, particularly in the United States and France, is to strengthen the legislation on audited published accounts. The importance of an audit committee is seen to be increased, with the role of providing an independent and reliable control at the company in order to strengthen the confidence of investors and all stakeholders but also to be the link between the external auditor, the company and the stakeholders, so as to allow a legal audit quality in all its components. The competence of the members of audit commitee, is linked to their accounting and financial expertise what are crucial for the quality of internal and operational audits (Krishhnan Schauer J. and P. (2000). Subramaniam, 2007), and even external in that it limits the management accounting manipulations and improve the quality of published financial information (Carcello et al 1992; Carcello 2000, Anderson et al, 2003; Piot et Janin, 2008).

\subsection{Auditor independence indicators}

Auditor's independence met a significant part of audit work. Independence is seen as the raison d'être of auditing, it is the heart of audit (Wolf, 1979, Whittington et Pany, 1995). Auditing is at the middle of various interests, and the auditor is at the center of this diversity. To represent as much as possible the interests of its actual agents who are the shareholders and by extension stakeholders (Richard, 2003) the auditor should not only be really independent, but also he should do everything to show noticeable signs of his independence to various stakeholders. It deals with how these stakeholders will perceive that independence, effective or damaged, including shareholders, investors and the financial market in general (Wolnizer 1987, Grenier et al. 2012). To appreciate this so perceived independence, theorists have adopted the auditor's behavior in response to threats surrounding its audit activity. The existing literature mainly covers four main threats studied: the importance of the customer in the Auditor's portfolio, parallel consultation and counseling services called "non-audit services" or management advisory services, the audit tenure, and finally the auditor affiliation with CPA firms (Lin et Téplagul, 2009). It could be linked to those studies auditors' independence psychological studies (Kung et Huan, 2011).

Client's importance is considered as a threat to auditor's independence. The risk of compromising independence being here linked with the fact that the auditor, given the significant financial weight occupied by a company in its customer portfolio and thus lining the survival of his organization will try to conceal any anomaly discovered during verification, or at best mitigate it, protecting the life of the audited company and therefore his own life. The financial arm's length is a must; the auditor's being remunerated by his client (De Angelo, 1981). When on that auditor's remuneration depends the survival or else when omen for him growing economic gains, there is great risk that he acts on behalf of the client (Blay, 2005). Krishnan and Krishnan (1996) report that since the customer deserves a reasoned opinion, auditors are less likely to motivate their opinion when the position of a customer in relation to others in their portfolio is higher.

Non audit services is one of the most studied aspects on the issue (Lin et Téplagul, 2009). This point mobilizes significant literature as a threat to auditor independence, although the renewed skepticism produced (Francis and Ke, 2006). Thus, theorists consider that the audit firms and their subsidiaries must legally exclude marketing services and management advisory services to their audit clients because it does not directly promote the interests of investors in search of reliable reports on financial statements. Kornish and Levine (2004) believe that the higher the level of consultancy services offered, the greater the relationship between the auditor and auditee becomes dangerously friendly. The quality of the auditor-auditee relationship becoming "friendly" with time, it will be easier for the auditor to protect that relationship and revenue relating thereto. Wines (1994) for example identified significant growth of fees from non-audit services in its sample of American CPA firms. These fees passed by consideration of a general average of 64 500 American dollars in 1980, to an amount of 617,800 dollars in 1989. 
Audit tenure represents the number of years of engagement between a company and an auditor for audit services. A priori, the literature considered that the higher the auditor tenure, the longer the relationship with the customer will become warm, so it would be more likely for the auditor to act in favor of the company, reducing audit quality (Téplagul and Lin, 2009). Audit tenure would have a derogatory effect on independence. Deis and Giroux (1992) believe that audit quality is inversely proportional to audit tenure, and therefore the more it lasts, the higher the quality decline. In agreement with them, Simnett and Carey (2006) found that in Australia an audit long tenure partnership is linked to a low propensity to produce from auditor a reliable and relevant audit report, hence the need to think of a rotation of independent auditors Mohamaed and Habib, 2013).

lmhoff (1978) raise three potential problems that could lead to the deterioration of the independence of the auditor in relation to the issue of affiliation with his client. The auditor could see the customer as a potential employee, the proximity to the company can create a distance between the auditor and the shareholders who are in fact his real employers, and finally the difficulty for audit team members to remain independent when working with their former colleagues.

\section{Problem}

An important note for the validity of earlier work is the spatio-temporal context in which they were conducted. Those works generally and implicitly accepted the assumption of audit quality linked to a form of premise, a backlit setting for basic control imposed by the stock exchange market. It can be seen for example that all research and results have been extracted from listed companies, sufficiently active in the financial market. However, several African countries in general, and in particular OHADA ones are structurally different from the wide environments of audit research studies. The overwhelming part of audit research works are done in America (Lin and Teplagul, 2008). Due to the significant differences between American economic and financial context and other countries context, the research needs to be extended (Lin and Teplagul, 2008).

Rapid changes in governance were instituted after the Enron-Arthur Anderssen scandal, and others that followed, encouraging at is improved managerial transparency, modernization of financial markets, (central organ that have carried the reforms). Some decisions like strengthening control institutions such as Securities and Exchange Commission, the accountability of the financial markets authority, the publication requirements of audit fees for certain listed companies; the enhanced level of audit committee and its independence... have been taken. Such actions have helped to improve and stabilize the practice of auditing, and create an environment where auditor's competence and independence could be transparently observed.

OHADA space companies did not experienced such changes. The current auditing environment characterized by the virtual presence of financial markets, lack of transparency, absence of confidence in the audited financial statements, seems to be an inappropriate frame where observing auditor's work would be very difficult, if not impossible. This state makes it difficult to consider prior theoretical indicators of audit quality to assess auditor's work. It is not possible, given the absence of a monitoring framework that could provide confidence and renewed data, to observe the level of competence, or to perceive auditor independence.

Similarly, various laws meant to guarantee audit quality seems at times inadequate, overtaken by the rapidity of systems evolution and management techniques. Because of their lack of dynamism (Tchakoute and Bita, 2009), it appears important to search for specific indicators of audit quality which can easily lend to contextual and environmental realities. This concern led to ask what can be the indicators of audit quality for OHADA space companies. The objective will be then to obtain some audit quality indicators where there is a lack of transparency and information flow.

\section{Methodology}

\subsection{Brief Description of OHADA States Auditing Environment}

OHADA is a legal environment, a system of business laws and implementing institutions adopted by seventeen West and Central African nations. OHADA is the French acronym for "Organisation pour l'Harmonisation en Afrique du Droit des Affaires", which translates into English as "Organization for the Harmonization of Business Law in Africa". It was created on October 17, 1993 in Port Luis, Mauritius.

As a West and Central African initiative to harmonize business laws and implementing institutions, OHADA aims to find alternative solutions to the lack of economic growth in sub-Saharan Africa - a region which has challenged and puzzled development economics for several decades. The stated purpose of the initiative is to facilitate and encourage both domestic and foreign investment in the member states, and seeing as how most of the participating countries are former French colonies, they draw chiefly on a modernized French legal model to achieve their goals. The laws promulgated by OHADA are exclusively business-related. The OHADA treaty has created a supranational court to ensure uniformity and consistent legal interpretations across the member countries, and the French influence in court proceedings is apparent (Dickerson, 2007). 
The OHADA accounting system, part of the OHADA uniform act, is not based on market logic (Feudjo, 2007). In all the involved countries, state remains the main agent of institutional frameworks 'development. The recent creation of stock markets (Douala Stock Exchange, BRVM in Abidjan) aimed to give a new face to accounting and auditing practice in OHADA countries. Unfortunately, the shy functioning of these stock exchanges and low adhesion of local businesses require a redefinition of new rules from which the accounting systems should be observed and evaluated. Integration into a more or less international system implicitly ambitioned by adopting these rules seems delayed, and sluggish markets make even more specific contemporary practices of accounting and auditing in member countries.

\subsection{Access to real strategy}

As such, an exploratory study appears to be essential in order to carry out this research. We especially want to understand what audit process characteristics auditors during their mission should be to pay attention to improve audit quality.

The study considers the perceptions of audit committee's member's indicators inherent to audit process and actions that could improve audit quality. The selection of members of audit committees is explained by the fact that they play a central role in information flow (Compernholle, 2009), and their effective presence within a company improves the quality of external audit of that company (Pucheta-Martinez and de Fuentes (2007). Moreover, the adoption and implementations of audit committees in OHADA space companies is a new and ongoing phenomenon, which could let believe that they are really playing a substantial role in safeguarding shareholders interests. The gradual implementation of such a governance body by local companies is then a good revealer of their central role in assuming audit quality.

The objective of this research is to develop contextual indicators of audit quality according to audit committee's members. To achieve this objective, we found the case study method to be the most appropriate (Marshall and Rossman, 2011). It is defined as an empirical inquiry that investigates a contemporary phenomenon in its real context (Yin, 1989). By choosing this method, the goal is to have an idea as comprehensive as possible of the studied phenomenon.

Regarding the sample size, the case method allows the use of multiple cases and the comparative study of cases to have a more precise idea on the behavior of firms facing a relatively new phenomenon. In total, seven companies with an audit committee constitute the sample of this research. This choice of then was based on two principles: Replication and saturation. According to these principles, it is necessary to study at least two or three cases while expecting similar results. If this observation is done, then the results will be more reliable. With the latter principle, it is no longer necessary to conduct studies for additional cases if they do not provide new information

The seven companies that make up the sample were selected according to two main criteria: the existence and regular functioning of an audit committee, and their involvement in appointing and selecting the external auditor. This approach aims to ensure that the audit committee is not limited at esthetics duties, and is really committed to improving the quality of the external audit. Banks and assurances have also been excluded from the study, due to their specific characteristics.

Most experienced managers made themselves available for the survey. The following table summarizes the characteristics of the sample. For confidentiality reasons, the names of the studied companies were replaced by numbers.

Table 1. Studied Companies and their characteristics

\begin{tabular}{lll}
\hline Companies & Sector of activities & Numbers of interviews \\
\hline Company 1 & Agribusiness & 08 \\
Company 2 & General trade & 05 \\
Company 3 & Retail & 06 \\
Company 4 & Soft drinks & 08 \\
Company 5 & Agribusiness & 06 \\
Company 7 & pharmaceutical industry & 05 \\
\hline
\end{tabular}

Several data collection techniques can be mobilized in a case study. According to the objectives, two techniques are preferred, including in-depth interviews and documentary analysis (Marshall and Rossman, 2011; Turki, 2014). In this work, data collection was based mainly on semi-structured interviews conducted with audit committee's administrators. Among the interviewees, three are chairs of their audit committee. A total of 38 interviews were made.

The discussed topics were chosen according to the study of Manita (2008), Viet $\mathrm{Ha} \mathrm{Vu} \mathrm{(2012):} \mathrm{The} \mathrm{first} \mathrm{topic} \mathrm{aims} \mathrm{to}$ better understand the different roles played by audit committees, and their relations with external auditor. The second topic was related to audit quality indicators, and the determinants of audit quality process. We interviewed participants on observable steps of audit process, and thereafter, we listed the different criteria they identified. After, we discussed with administrators on the way they assess audit quality, and on their communicating method with external auditors. 
Once the data recovered, they have been we exhaustively transcribed. Then, by interviewee, a synthesis of responses was made. These syntheses have been resubmitted to them, in order to avoid any misinterpretation of their opinions. Moreover, they were given opportunity to give additional information, if they found necessity.

After this step, a content analysis was carried out with the transcribed data. Analysis was performed in two steps: A thematic analysis for each case was conducted. Next, a vertical and horizontal thematic analysis of the interviews was done. This is to give each interview a broader thematic structure of its own (vertical analysis) and comparing all the interviews on their global thematic structures (horizontal analysis). This helps not to consider the singular consistency of each case, but rather to seek an overall coherence at the body of data produced by all the interlocutors. We then look for the occurrence, the pertinence and the meaning of topics from an interviewee to another.

\section{Results}

The first result of this study show that audit committee could intervene at two principal levels in the audit process: Before the process at the level of the selection of the external auditor, during the process by evaluating the quality of the auditor's work.

Audit quality indicators are then related to the second part of their intervention, it means during the audit process. Audit committees administrators share what they perceive as audit quality indicator according to audit process step. Three steps have therefore caught the attention of the administrators considered as the main essential component phases of an audit: The understanding of systems and assessment procedures of the audited company, the audit of the accounts, and the certification of the correctness of the financial statements.

Concerning now audit quality indicators analyzed according to audit committees members, 32 items were identified first. We have refined these items by observing those of them that were intuitively redundant, to reach to a scale of 21 items determinants of audit quality.

As Manita (2008), a comparison of the results was performed with the quality indicators established by previous studies using the same approach (Aldesier, 1995 Carcello et al. 1992) and by studies that examined the audit process. Finally, we reached at a final number of 16 items. The following table summarizes the final audit quality determinants underlined by the study:

Table 2. Audit Quality Determinants underlined by the study

\begin{tabular}{ll}
\hline $\mathrm{N}^{\mathrm{o}}$ & Items \\
\hline 1 & Good knowledge of the company and its information system \\
2 & Good knowledge of company's specificities, its activities sector, and the risks of the job \\
3 & Good knowledge of the risks and sensitive areas of the company \\
4 & Good exploitation of internal reports, realized by experts in risk appreciation \\
5 & Reliability of weaknesses and sensitive points underlined by internal control reports \\
6 & Real commitment of the chartered accountant in charge of the mission \\
7 & Number and quality of meetings with the audit committee \\
8 & Quality and follow up of past years identified risks \\
9 & Compliance to the specification of the audit engagement \\
10 & Quality of follow up and physical inventory \\
11 & Pertinence of the audit mission synthesis \\
12 & Level of expertise of audit mission's members \\
13 & Level of independence of intervening audit team and of the chartered accountant \\
14 & Quality of communication between the members of audit team and internal controllers \\
15 & Quality of audit reports \\
16 & Level of auditor independence while rendering its opinion on accounts reliability \\
\hline
\end{tabular}

\section{Conclusion and Implications of the Results}

These results imply two main remarks: First we realize that audit quality is fundamentally dependent of the mastery of the three main steps of an audit: Before the process starts, the auditor should well know the company and its environment. This knowledge will install the conditions of a good mission, and minimize the risk of an irrelevant appreciation of potential risks before the audit.

After it, the second step leads auditor during the audit process to have a good level of relevance in identifying critical risks zones, and in collaborating with the board of directors or its representation, that is the audit committee. This point comprises the major and the most numerous items, which could be noted from level 5 to level 13 of the table.

Finally, the auditor should be totally independent when pronouncing his judgment about the true and fair view of the financial statements. All the criteria and items break with perceived factors of audit quality, which are perceived auditor's 
independence and competence. A global model of audit quality determinants could therefore be outlined from the summarized results:

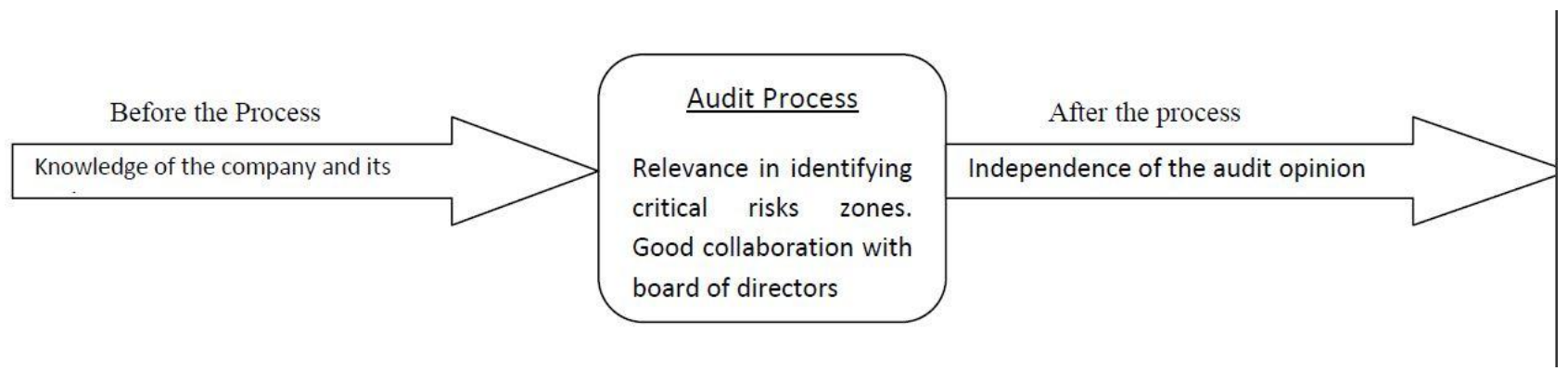

\section{Synthesis and discussion}

Following a case study methodology, we realized a qualitative analysis via interviews conducted with audit committee's members in Cameroon, a country member of OHADA. Obtained results lead us to put in evidence 18 indicators determinants of audit quality. These determinants constitute the basis of an assessment of external audit by audit committees. They show that audit quality, beyond auditor's capacities (competence and independence) is also determined by aspects related to considerations before the beginning of audit process and thereafter, at the moment of giving his opinion.

Our research results are partially similar to those of Manita (2008) who conducted a similar research with some Tunisian listed companies. Anyway, the items identified by the study are few than hers. This difference could be explained by the listed character of the companies of her eompany's-sample, and the churchill's methodological approach she used.

The main limitation of this study is the low number of cases included in the study. Taking into account other cases could enhance the quality of the results. Then use speeches and documents as data collection technique may not provide a clear idea on the studied phenomenon (Turki, 2014). It would be interesting in this title in the future to opt for action research to better understand the perception of audit committee's administrators.

\section{Reference}

Adjaoud, F. al. (2007). La réputation de l'audit externe et les mécanismes de gouvernement, d'entreprise : Effets et interactions sur la performance ; 28e congrès de l'AFC, Poitiers, 22.

Aldesier, G. R., Miler, J. R., \& Moraglio J. F. (1995), Common attributes of quality audits, Journal of Accountancy, 179(1), 61-70

Blay, A. (2005). Independence threats, litigation risk, and the auditor's decision process. Contemporary Accounting Research, 759-789

Chow C., Cooper J., \& Waller, W. (1988). Participative budgeting: effect of truth-industry pay scheme and information asymmetry on slack and performance. The Accounting Review, 111-122

Compernholle, T. (2009). La construction collective de l'indépendance du commissaire aux comptes : La place du comité d'audit, Comptabilité-Contrôle-Audit, 15(3), 91-116

De Angelo, L. (1981a). Auditor independence, low balling, and disclosure regulation; Journal of Accounting and Economics, 3, 113-127.

De Angelo, L. E. (1981b).Auditor size and audit quality, Journal of Accounting and Economics, 3, 183-199

Deis, J., \& Giroux, A. (1992); Determinants of audit quality in the public sector. The Accounting Review, 462-479

Dickerson, C. (2007).Harmonizing Business Laws in Africa: OHADA calls the Tune, Communication, 18th December

Fama, E., \& Jensen, M. (1983). Agency problems and residual claims", Journal of Law and Economics

Flint. (1998).Philosophy and principles of auditing, Macmillan Education, London

Grenier, J., Pomeroy, B., \& Reffett, A. (2012).When do auditor defense tactics increase rather than decrease perceived auditor negligence? Current Issues in Auditing, 6, 7-12

Imhoff, Jr. (1978). Employment effects on auditor independence. The Accounting Review, 869-881.

Krishhnan, J., \& Schauer. P. (2000). The differenciation of quality among auditors: evidence from the not-profit sector", 
Auditing: A Journal of Practice and Theory, 19, 9-25

Krishhnan, J., \& Schauer, P. (2000). "The differenciation of quality among auditors: evidence from the not-profit sector", Auditing: A Journal of Practice and Theory

Kung, H., \& Huang, C. (2011); Auditor's Moral Philosophies and Ethical Beliefs», Management Decision, 51(4), 13.

Ling, L., \& Teplagul, K. N. (2009). Auditor Independence and audit Quality: A literature Review», disponible à

Manita, R. (2009). La qualité du processus d'audit : une étude empirique sur le marché financier tunisien». Comptabilité - contrôle audit, 15(2), Paris, 49-64

Marshall, C., \& Rossman, G. (2011). Designing qualitative research, Sage Publications, 354.

Mohamaed, M. D., \& Habib, H. M. (2013).Auditor independence, audit quality and the mandatory auditor rotation in Egypt; Education, Business and Society: Contemporary Middle Eastern Issues, 6(2), 116-144

Pucheta-Martinez, M. C., \& Fuentes, C. de (2007). The impact of audit committee characteristics on the enhancement of the quality of financial reporting: An empirical study in the Spanish context. Corporate Governance: An International Review, 15(6), 1394-1412.

Richard, C. (2003).L'indépendance de l'auditeur : Pairs et manques », Revue française de Gestion No 147, PP. 119-131

Simnett, R., \& Carey, P. (2006).Audit partner tenure and audit quality. The Accounting Review, 653-676

Viet Ha, T. V. (2012). Les dimensions de la performance des cabinets d'audit légal : Le point de vue des auditeurs, Comptabilité-Contrôle-Audit, Tomem, 18(3), 97-143

Watts R., \& Zimmermann, J. (1981). Auditors and Determination of Accounting Standards", Working Paper, University of Rochester.

Watts, R. L., \& Zimmerman, J. L. (1986). Positive accounting theory”, Prentice-Hall, Contemporary Topics in Accounting Series, Englewood Cliffs, New Jersey

Whittington, O. R., \& Pany, K, "Principles of Auditing" (11th ed, 1995).

Wines, G. (1994). Auditor independence, audit qualifications and the provision of non-audit services: a note, Accounting and Finance.

Wolnizer, P. W. (1987). Auditing as independent authentication», Sydney University Press

Woolf , E. (1979). Auditing Today.

\section{(c)) EY}

This work is licensed under a Creative Commons Attribution 3.0 License. 